PARIDE DIOLI $(*)$ - ANDREA D. COLAMARTINO $(* *)$ - MARCO NEGRI $(* * *)$ - LIDIA LIMONTA $(* *)$

\title{
HEMIPTERA AND COLEOPTERA ON CHENOPODIUM QUINOA
}

\author{
(*) Museo Civico di Storia Naturale di Milano, Corso Venezia 55, 20121 Milano - Italy \\ (**) DeFENS, Università degli Studi di Milano, Via Celoria 2, 20133 Milano - Italy \\ (***) DISAA, Università degli Studi di Milano, Via Celoria 2, 20133 Milano - Italy \\ Corresponding author: lidia.limonta@unimi.it
}

Dioli P., Colamartino A.D., Negri M., Limonta L. - Hemiptera and Coleoptera on Chenopodium quinoa.

Heteroptera and Coleoptera, collected in experimental fields of Chenopodium quinoa, are reported. Twelve species of Heteroptera and five species of Coleoptera were recorded; a large number of the phytophagous species, Lygus rugulipennis, Orthotylus flavosparsus, Aphis craccivora, A. fabae and Chaetocnema tibialis, and of the predator Hippodamia variegata were found.

Key Words: Hemiptera, Miridae, Anthocoridae, Rhopalidae, Lygaeidae, Coleoptera, Coccinellidae, Chrysomelidae.

\section{INTRODUCTION}

Chenopodium quinoa Willd. is a plant of the family Amaranthaceae, and its cultivation is very ancient, the first historical data concerning the quinoa crop dates back to $5000 \mathrm{BC}$ in the Andean region, South America. Because of its high nutritional value, including the presence of all nine essential amino acids, its use has spread to several Western countries, where the cultivation was recently introduced. $C$. quinoa is infested by numerous insects in the Andean area, and reports from Northern Europe and from Southern Europe include moths, aphids, capsid bugs, leafhoppers, and leaf beetles (RASMUSSEN et al., 2003; SIGSGAARD et al., 2008). Experimental fields of quinoa have been sown in Northern Italy, with the aim of optimizing the agrotechniques in our Country. The presence of several specimens of Nysius cymoides (Lygaeidae), parasite of native Chenopodiaceae, was recorded in 2014 in San Giorgio Piacentino (Piacenza) (BocCHI et al., 2016, in press). In 2015, additional sampling in experimental fields, revealed the establishment of phytophagous Hemiptera and Coleoptera and their predators.

\section{MATERIALS AND METHODS}

In 2015, crops of Chenopodium quinoa were monitored in Alseno and Gossolengo (Piacenza province), and in Ceresara (Mantova province). Pea (Pisum sativum), corn (Zea mays) and soy (Soja hispida) crops, and spontaneous plants like velvet leaf (Abutilon theofrasti), white goosefoot (Chenopodium album), common chamomile (Matricaria chamomilla), Aleppo grass (Sorghum halepense) and hairy vetch (Vicia villosa), were present in Alseno; in Gossolengo, pea and sweet corn were cultivated, and redroot pigweed (Amaranthus retroflexus), white goosefoot (C. album), hop (Humulus lupulus), bittersweet nightshade (Solanum dulcamara), and black nightshade (S. nigrum), developed as weeds; corn and soy were grown in Ceresara, white goosefoot (C. album), ribwort plantain (Plantago lanceolate), and broadleaf plantain ( $P$. major) occurred as uncultivated plants. Panicles of quinoa, from different areas of the fields, were collected and examined in the laboratory in July and in August.

Plants of quinoa, grown in pots, were monitored in Milano. In this case, insects were collected from the plants, placed in vials, and observed in the laboratory.

\section{RESULTS AND DISCUSSION}

Table 1 lists the species and the number of Hemiptera and Coleoptera collected in the province of Piacenza and Mantova, and in Milan; only Aphis species were not counted as, when present, they occurred in large colonies. Fourteen phytophagous species and three predators, linked to the phytophages, were collected. All the species recorded are common in Italy. Many of the species can colonize crops and field margin vegetation, especially white goosefoot (Chenopodium album), plant that belongs to the same family of quinoa, Amaranthaceae, recorded in Alseno, Ceresara, and Gossolengo.

Among Hemiptera Heteroptera, Mirids colonize wild vegetation bordering crops and they can move from the spontaneous plants to the crops. Lygus rugulipennis (Poppius, 1911), the most abundant species, is a palearctic, well-known pest of spontaneous and cultivated plants. It colonizes sunflower, apple orchard, vineyard, Matricaria sp., Rumex sp., Trifolium sp. and Urtica dioica, (WAGNER and WeBer, 1964). It is recorded also on Chrysanthemum sp., Medicago sativa, Nicotiana tabacum, Rubus idaeus, Sesamus indicum, Solanum tuberosum and Triticum sp.; damages are observed on bud, fruit, and leaf (SouTHWOOD and LESTON, 1959). Also Orthotylus flavosparsus (Sahlberg, 1842), palearctic species, colonized quinoa in all the three localities, coming from spontaneous plants of the same family; it is a bivoltine species, the first adults are observed in June, the adults of the second generation appear in August-September, and the species overwinters as egg (WAGNER, 1970-1975). Monitoring of Polymerus cognatus 
Table 1 - Species and number of Hemiptera and Coleoptera recorded in Alseno (PC), Ceresara (MN), Gossolengo (PC), and Milano, total number of specimen and percentage.

\begin{tabular}{|c|c|c|c|c|c|c|}
\hline Species & Alseno & Ceresara & Gossolengo & Milan & Total & $\%$ \\
\hline \multicolumn{7}{|l|}{ HEMIPTERA } \\
\hline \multicolumn{7}{|l|}{ MIRIDAE } \\
\hline Adelphocoris lineolatus (Goeze) & & & 1 & & 1 & 0.2 \\
\hline Lygus rugulipennis (Poppius) & 37 & 14 & 164 & & 215 & 45.2 \\
\hline Lygus pratensis (L.) & & & 1 & & 1 & 0.2 \\
\hline Orthotylus flavosparsus (Sahlberg) & 39 & 8 & 11 & & 58 & 12.2 \\
\hline Polymerus cognatus (Fieber) & 1 & 9 & & & 10 & 2.1 \\
\hline Liocoris tripustulatus (F.) & & & & 6 & 6 & 1.3 \\
\hline \multicolumn{7}{|l|}{ ANTHOCORIDAE } \\
\hline Orius niger (Wolff) & 1 & 7 & & & 8 & 1.7 \\
\hline \multicolumn{7}{|l|}{ RHOPALIDAE } \\
\hline Liorhyssus hyalinus (F.) & 2 & - & 1 & & 3 & 0.6 \\
\hline \multicolumn{7}{|l|}{ LYGAEIDAE } \\
\hline Nysius ericae (Schilling) & & & & 4 & 4 & 0.8 \\
\hline Nysius graminicola (Kolenati) & & & & 1 & 1 & 0.2 \\
\hline \multicolumn{7}{|l|}{ APHIDIDAE } \\
\hline Aphis craccivora Koch & & & & $* *$ & & \\
\hline Aphis fabae Scopoli & & & & $* *$ & & \\
\hline \multicolumn{7}{|l|}{ COLEOPTERA } \\
\hline \multicolumn{7}{|l|}{ CHRYSOMELIDAE } \\
\hline Chaetocnema tibialis (Illiger) & 113 & 25 & 2 & & 140 & 29.5 \\
\hline Chaetocnema picipes Stephens & 1 & & & & 1 & 0.2 \\
\hline Phyllotreta vittula (Redtenbacher) & & 3 & & & 3 & 0.6 \\
\hline \multicolumn{7}{|l|}{ COCCINELLIDAE } \\
\hline Hippodamia variegata Goeze & 5 & 16 & 1 & & 23 & 4.8 \\
\hline Scimnus rubromaculatus (Goeze) & & 2 & & & 2 & 0.4 \\
\hline
\end{tabular}

** High number of specimens.

(Fieber, 1858) is particularly interesting as in Italy it is usually recorded in salty habitat of the peninsula coast on Salsola kali and other Salsolaceae, but it is also present in marsh (Dioli, 1995). Lygus pratensis (Linnaeus, 1758) and Liocoris tripustulatus (Fabricius, 1781) are common in rangelands and the presence on quinoa could be accidental, as Adelphocoris lineolatus (Goeze, 1778), holarctic species, that thrives mainly on Papilionaceae and Asteraceae (DiOLI, 1997), and is a pest of alfa-alfa, clover, cotton, jujube, and legume (ZHANG et al., 2015). Few specimen of Liorhyssus hyalinus (Fabricius, 1794) were collected. This cosmopolitan Rhopalidae is recorded mainly on Asteraceae and Poaceae (Moulet, 1995). The only predator in Hemiptera, Orius niger (Wolff, 1811) (Anthocoridae), was mainly collected in Ceresara. This species is spread in Europe and in Central Asia, it preys on aphids and thrips (Dioli, 1992), on Artemisia spp., Achillea spp., and Verbascum spp. (PERICART, 1972).
The turanic-mediterranean Coleoptera, Chaetocnema tibialis (Illiger, 1807) was abundant. Adults damage heavily Beta vulgaris leaves, while larvae feed on roots. Only one specimen of $C$. picipes (Stephens, 1831) was recorded, usually present on Polygonaceae. Another leaf beetle was collected, Phyllotreta vittula (Spinola, 1844), known to colonize cereals, and also in this case its presence on quinoa can be considered accidental.

Two species of Coccinellidae were collected, Hippodamia variegata (Goeze, 1777) and Scymnus rubromaculatus (Goeze, 1777), both predators of aphids; the two genera were already recorded on quinoa (DUGHETTI, 2015).

The insects collected on quinoa, cultivated in pots, in Milan were different from the species collected in the open fields. Two phytophagous Lygaeidae were collected, Nysius ericae (Schilling, 1892), eurasiatic, polyphage on Asteracee and on Fabaceae (PERICART 1998), and Nysius graminicola (Kolenati, 1845), a xerophilic, turanic-mediterranean 
species, found on Poaceae (STICHEL, 1959-1961), and Asteraceae (PERICART, 1998). The presence of Nysius cymoides, recorded in 2014 on quinoa (BocCHI et al., 2016), suggests the propensity of Lygaeidae to Amaranthaceae. In September, quinoa in Milano was colonized by two polyphagous aphids, Aphis craccivora (Koch, 1854) and Aphis fabae (Scopoli, 1763).

\section{AKNOWLEDGMENTS}

We thank Carlo Leonardi and Claudio Canepari of "Museo civico di Storia Naturale di Milano" for the identification of Coleoptera, and Matteo Bertoglio and Francesca Bardi for help in field survey.

\section{REFERENCES}

Bocchi S., Cinquanta D., Negri M., Dioli P., Limonta L., 2016 - Nysius cymoides (Spinola) on Chenopodium quinoa Willd. cultivated in Italy. - J. Ent. Acar. Res. 48 (3): in press.

Dioli P., 1992 - Esame del Popolamento degli Eterotteri (Insecta, Heteroptera) negli strati bassi dell'atmosfera sul Delta del Po. - Boll. Mus. civ. St. nat. Venezia, 41: 183-205.

Dioli P., 1995 - Eterotteri del Ferrarese: 1. La Fauna terrestre. - Quad. Staz. Ecol. Civ. Mus. St. nat. Ferrara, 8: 7-49.

Dioli P., 1997 - Eterotteri (Heteroptera) del Monte Barro (Italia, Lombardia, Lecco). - Mem. Soc. It. Sci. Nat. e Mus. Civ. St. Nat. Milano, XXVII (2): 159-174.

Dughetti A. C., 2015 - Plagas de la quinua y sus enemigos naturales en el valle inferior del Rio Colorado, Buenos
Aires, Argentina. Manual de la E. E. A. Hilario Ascasubi. - INTA Ediciones. Buenos Aires, Argentina.

Moulet P., 1995 - Hemiptères Coreoidea (Coreidae, Rhopalidae, Alydidae), Pyrrhocoridae, Stenocephalidae euro-mediterranéens. Faune de France, 81: 1-336.

Pericart J., 1972 - Hémipteres Anthocoridae, Cimicidae, Microphysidae de l'Ouest-Paléarctique. Faune de l'Europe et du Bassin Méditerranéen. Vol.7 : IV + 402 pp. Masson et C.ie, Paris.

PERICART J., 1998 - Hémiptères Lygaeidae euroméditerranéen. Faune de France 84 (A). Fédération Française des Sociétés de Sciences naturelles, Paris.

RASMUSSEN C., LAGNAOUI A., ESBJERG P., 2003 - Advances in the knowledge of Quinoa pests. - Food Reviews International, 19 (1 \& 2): 61-75.

SigsgaArD, L., JacobSEn, S. E., Christiansen, J. L. 2008 Quinoa, Chenopodium quinoa, provides a new host for native herbivores in Northern Europe: case studies of the moth, Scrobipalpa atriplicella, and the Tortoise Beetle, Cassida nebulosa. - J. Insect Sci., 8, 50.

Southwood T.R.E., Leston D., 1959 - Land and Water Bugs of the British Isles. Warne, London.

STICHEL W., 1955/1962 - Illustrierte Bestimmungstabellen der Wanzen. II. Europa. Voll. I-IV, Berlin.

WaGner E., 1970-1975 - Die Miridae Hahn, 1831, des Mittelmeerraumes und Makaronesischen Inseln (Hemiptera, Heteroptera). - Ent. Abhandl. St. Mus. Tierk. Dresden., Suppl., Band. 37, 39, 40: 1- 1388.

Wagner E., Weber H.H., 1964 - Héteroptères Miridae. Faune de France. 67: 1-589.

Zhang T., Mei, X.D., Li Y.F., Zhang K.X. , Wu K.M., Ning J., 2015 - Sex pheromone of the alfalfa plant bug, Adelphocoris lineolatus. - Ent. Exp. Appl., 156 (3): 263-270. 
